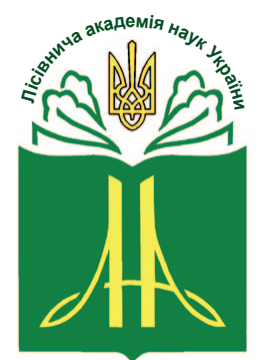

Forestry Academy of Sciences of Ukraine
Наукові праці Лісівничої академії наук України Proceedings of the Forestry Academy of Sciences of Ukraine http://fasu.nltu.edu.ua https://doi.org/10.15421/412026

Article received 2020.05.22

Article accepted 2020.12.28
ISSN 1991-606X print

ISSN 2616-5015 online

@ $₫$ Correspondence author

Hryhoriy Krynytskyy

krynytsk@ukr.net
General Chuprynka str., 103, Lviv, 79057, Ukraine

УДК [630*174.754:630*176.322.2]:581.148] (477.83)

\title{
Динаміка опаду в сосново-букових деревостанах та її зміни за впливу поступових рубок в умовах Львівського Розточчя
}

\author{
В.Й. Яхницький', Г.Т. Криницький
}

Висвітлено особливості річної динаміки нагромадження опаду, його структурних фракцій (хвоя сосни, листя бука, листя супутніх порід, гілки, кора, шишки сосни, горішки бука, пліски горішків бука, насіння супутніх порід) та їхніх змін після проведення перших прийомів поступових рубок головного користування рівномірних поступових і трупово-вибіркових в унікальних за складом та обмежених за поширенням сосновобукових лісостанах Львівського Розточчя. Залежно від лісівничо-таксаційних показників стиглих сосновобукових деревостанів, річна маса опаду становить, зазвичай, 5-6 m·га в в абсолютно сухому стані. Найбільшу частку опаду в річному цуиклі становить листя бука (29,5-36,8\%), значно меншу - хвоя сосни (20,8-25,6\%). Достатньо значимою в складі опаду смаса гілок (12,4-14,7\%), иишок сосни (10,5-11,7\%), кори дерев (6, 6-9,0\%) і плісок горішків бука (3,6-10,6\%). Невеликою часткою опаду представлені горішки бука (1,7-4,3\%) та листя супутніх порід (0,4-1,7\%) і найменшою - насіння супутніх порід (0,01-0,13\%).

Найбільша маса опаду формується в жовтні (35,6-44,6\%). Значна кількість мертвої фітомаси опадає також у вересні (14,1-16,2\%) та в осінньо-зимово-весняний період (листопад - березень, 19,3-19,7\%). Невелике збільшення опаду в сосново-букових деревостанах Львівського Розточчя є характерним $і$ для травня $(8,4-14,3 \%)$.

Найменша кількість фітомаси опадає в квітні (близько 2,0\%). Невелику частку опаду спостережено також у липні (2,9-3,7\%) і в серпні (2,7-3,7\%).

Річна динаміка нагромадження окремих фракиій опаду в сосново-букових лісостанах є неоднозначною. Найбільша маса хвої сосни опадає у вересні (29,0-33,2\%) або у жовтні (26,4-40,2\%), листя бука та супутніх порід у жовтні (відповідно, 84,5-87,4\% і 81,0-81,2\%), гілок-у зимовий період (38,9-63,6\%) або у травні (13,1-45,3\%), кори - у зимовий період (39,7-43,1\%), шишок сосни - в травні і червні (відповідно, 26, 7-38,0\% і 28, 7-38,8\%), горішків бука - у вересні (54,2-58,7\%), плісок горішків бука - у вересні і зимовий період (відповідно, 17,9-23,2\% $i$ 40,7-53,0\%), насіння супутніх порід - у жовтні (57,1-70,7\%).

Після проведення першого прийому рівномірної поступової рубки річна маса опаду зменшилась до 44,3\%, a групово-вибіркової- до 62,1\% порівняно з контролем. При изьому річна динаміка опаду $і$ його фракцій після рубок істотно не змінилася.

Ключові слова: сосна; бук; супутні деревні породи; річні циикли; опадання фітомаси; фракції опаду; рівномірно поступова і групово-вибіркова рубки.

Яхницький Володимир Йосипович - здобувач кафедри лісівництва. Національний лісотехнічний університет України, вул. Генерала Чупринки, 103, м. Львів, 79057, Україна. Тел.:+38-096-021-11-92. E-mail: krynytsk@ukr.net

2 Криницький Григорій Томкович - науковий керівник, академік Лісівничої академії наук України, Президент ЛАН України, доктор біологічних наук, професор, завідувач кафедри лісівництва. Національний лісотехнічний університет України, вул. Генерала Чупринки, 103, м. Львів, 79057, Україна. Тел.: 032-237-89-05, +38-067-784-11-60. E-mail: krynytsk@ukr.net 
Вступ. Опад деревних порід $є$ важливим компонентом лісостану і вагомою ланкою колообігу органічних речовин та енергії в лісових екосистемах. На його основі формується лісова підстилка, розкладання якої значною мірою впливає на вміст гумусу у верхніх шарах грунту і мінеральне живлення рослин, інтенсивність мікробіологічних процесів та життєдіяльність безхребетних тварин (Морозов, 1949; Зонн, 1954; Похитон, 1957, 1958; Шумаков, 1963; Бондар, 2000; Кременецька, 2000; Рибак, 2004; Остапчук, 2012).

Кількісні та якісні показники опаду, які визначають структуру підстилки та інтенсивність її розкладу, залежать, насамперед, від видового складу рослин у лісостанах, а, особливо, від складу основного інтегруючого компонента біоценозу - деревостану та його лісівничо-таксаційних ознак (Висоцький, 1950; Ковалевський, 1952; Погребняк, 1968; Горшенин, Швиденко, 1977; Мелехов, 1980; Бондар, 2000; Криницька, 2015; Криницький, 2015; Krynytska et al., 2017). Важливе значення для формування опаду мають також лісогосподарські заходи, які проводяться у лісостанах, зокрема, рубки догляду і рубки головного користування (Бутейко, 1975; Криницька, 2015). Варто також зазначити, що на динаміку кількісних і якісних показників опадання мертвої органічної маси та іiї структурних елементів великий вплив мають пори року та регіональні кліматичні і грунтово-гідрологічні умови.

Сосново-букові лісостани $є$ малопоширеними. В Україні вони формуються лише на ЛьвівськоБережанському плато західного регіону держави та лісогірських районах Криму. Їх звужений ареал та унікальність зумовлюються фітоценотичним поєднанням у складі деревостану світлолюбного деревного виду - сосни звичайної і тіневитривалого бука лісового. Тому закономірності формування i складні процеси функціонування сосново-букових лісостанів вивчені недостатньо. Зокрема дослідженню особливостей нагромадження і розкладу опаду та підстилки в соснових субучинах присвячені лише публікації О.І. Бутейко (1964, 1975), які стосуються пристигаючих деревостанів і не враховують впливу змін клімату.

У зв'язку з цим, вивчення регіональних особливостей формування опаду впродовж року в різних за складом і продуктивністю сосново-букових лісостанах $є$ актуальним завданням.

Об'єкти та методика дослідження. Об' $є к m$ досліджень - сосново-букові деревостани в умовах Львівського Розточчя. Предмет досліджень - нагромадження опаду і його фракцій у річному циклі та зміни їхньої динаміки в процесі поступових рубок головного користування - рівномірної поступової та групово-вибіркової. Мета досліджень полягала у вивченні особливостей річної динаміки нагромадження опаду та його структурних фракцій у сосново-букових деревостанах і їх змін після проведення перших прийомів поступових рубок головного користування.

Дослідження здійснювали на двох стаціонарних ділянках, закладених у 2012 р. на теренах Львів- ського Розточчя, у Великопільському лісництві Страдчівського навчально-виробничого лісокомбінату Національного лісотехнічного університету України (Яхницький, 2015). Перша стаціонарна ділянка розташована в кв. 2, вид. 1, друга - на відстані 120-150 м від неї (кв. 1, вид. 17).

Для досліджень річної динаміки опаду та його фракцій на першій ділянці було вибрано контрольну (1) та експериментальну секції (2), де проводилась рівномірна поступова рубка. На другій ділянці дослідження здійснювались також на контрольній (4) та експериментальній (5) секціях, де проводилась групово-вибіркова рубка (табл. 1). Тип лісу на обох стаціонарних ділянках - волога грабово-соснова субучина, тип грунту - дерново-слабопідзолистий супіщаний. Вік деревостанів - 105-110 років, висота над рівнем моря - 340-365 м. Склад деревостанів на всіх досліджуваних секціях до проведення рубок був ідентичним (Яхницький, 2015). Перший прийом поступових рубок на експериментальних секціях проведений взимку 2012-2013 pp. Лісівничотаксаційні показники деревостанів після першого прийому поступових рубок наведено у табл. 1 .

За наведеними результатами (див. контрольні секції), на стаціонарних ділянках були сформовані стиглі високопродуктивні деревостани високої повноти і запасу. Головними лісотвірними видами виступають сосна звичайна і бук лісовий. Як невелика домішка, у складі деревостанів були представлені також граб звичайний, ялина європейська, явір, береза повисла, зрідка - клен гостролистий і в'яз шорсткий (див. табл. 1). Для стимуляції природного поновлення деревних порід і забезпечення достатнього світлового живлення для самосіву інтенсивність першого прийому рубок була високою $(29 \%$ - рівномірна поступова рубка і 51\% - групово-вибіркова).

Лісівничо-таксаційні показники деревостанів визначали за загальноприйнятою у лісовій таксації методикою (ОСТ 56-69-83, 1984). Для вивчення річної динаміки опаду і його фракцій використовували опадоуловлювачі розміром $1 \times 1$ м, які рівномірно, в геометричному порядку встановлювали на контрольних та експериментальних секціях у 12-разовій повторності. Відбір зразків опаду здійснювали щомісячно (за листопад - березень сумарно в березні). Відібрані зразки в лабораторних умовах розділяли на фракції (хвоя сосни, листя бука, листя інших порід, гілки, кора, шишки сосни, горішки бука, пліски горішків бука, насіння інших порід) та висушували їх до абсолютно сухого стану.

Результати досліджень. У мішаних сосновобукових лісостанах (табл. 2, див. контрольні секціï), впродовж року нагромаджується значна кількість опаду. Залежно від лісівничо-таксаційних показників стиглих деревостанів, річна маса опаду становить, зазвичай, 5-6 т.га⿰ стані. Близькі результати за масою опаду отримані також О. І. Бутейко (1975) в пристигаючих сосновобукових деревостанах Львівського Розточчя. Характерно, що подібна маса опаду формується і в поширених на Розточчі грабово-сосново-дубових лісостанах (Криницька, 2015). 


\section{Лісівничо-таксаційні показники деревостанів на секціях сосново-букових стаціонарів} після першого прийому поступових рубок

\begin{tabular}{|c|c|c|c|c|c|c|c|c|c|c|}
\hline \multirow{2}{*}{ 忽 } & \multirow{2}{*}{ Спосіб рубки } & \multirow{2}{*}{$\begin{array}{c}\text { Склад } \\
\text { деревостану }\end{array}$} & \multirow{2}{*}{$\begin{array}{l}\text { Індекс } \\
\text { породи }\end{array}$} & \multirow{2}{*}{$\begin{array}{l}\text { Вік, } \\
\text { років }\end{array}$} & \multirow{2}{*}{ 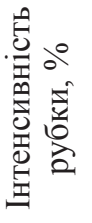 } & \multicolumn{2}{|c|}{ Середні } & \multirow{2}{*}{ 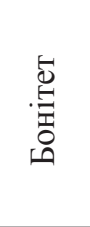 } & \multirow{2}{*}{ 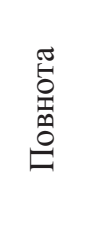 } & \multirow{2}{*}{$\begin{array}{l}\text { Запас, } \\
\mathbf{m}^{3} \cdot \mathbf{r a}^{-1}\end{array}$} \\
\hline & & & & & & $\mathrm{D}, \mathrm{cm}$ & $\mathrm{H}, \mathrm{M}$ & & & \\
\hline I & Контроль & $\begin{array}{c}\text { 6Сз4Бкл + Гз, } \\
\text { Ялє, Бп }\end{array}$ & $\begin{array}{l}\mathrm{C}_{3} \\
\text { Бкл }\end{array}$ & $\begin{array}{l}105 \\
105\end{array}$ & - & $\begin{array}{l}44,4 \\
30,1\end{array}$ & $\begin{array}{l}29,6 \\
26,7\end{array}$ & $\begin{array}{l}\mathrm{I}^{\mathrm{a}}, 8 \\
\mathrm{I}, 6\end{array}$ & 0,86 & 586 \\
\hline II & $\begin{array}{c}\text { Рівномірна } \\
\text { поступова } \\
\text { двоприйомна }\end{array}$ & 8Сз2Бкл + Ялє & $\begin{array}{l}\mathrm{C}_{3} \\
\text { Бкл }\end{array}$ & $\begin{array}{l}105 \\
105\end{array}$ & 29 & $\begin{array}{l}43,6 \\
37,3\end{array}$ & $\begin{array}{l}30,0 \\
28,8\end{array}$ & $\begin{array}{l}\text { Ia }, 8 \\
\text { II, } 0\end{array}$ & 0,51 & 349 \\
\hline III & Контроль & 6Сз4Бкл + Ялє & $\begin{array}{l}\mathrm{C}_{3} \\
\text { Бкл }\end{array}$ & $\begin{array}{l}110 \\
110\end{array}$ & - & $\begin{array}{l}36,2 \\
24,9\end{array}$ & $\begin{array}{l}26,4 \\
24,6\end{array}$ & $\begin{array}{l}\text { I, } 9 \\
\text { II, } 3\end{array}$ & 0,98 & 530 \\
\hline IV & $\begin{array}{c}\text { Групово-вибіркова } \\
\text { триприйомна }\end{array}$ & $\begin{array}{c}\text { 4Сз5Бкл1Гз+ } \\
\text { Яле, Бп }\end{array}$ & $\begin{array}{l}\text { С3 } \\
\text { Бкл }\end{array}$ & $\begin{array}{l}110 \\
110\end{array}$ & 51 & $\begin{array}{l}29,8 \\
30,1\end{array}$ & $\begin{array}{l}26,5 \\
26,7\end{array}$ & $\begin{array}{l}\mathrm{I}, 9 \\
\mathrm{I}, 7\end{array}$ & 0,41 & 226 \\
\hline
\end{tabular}

Таблиия 2

Річна динаміка маси опаду і його фракцій на секціях сосново-букових стаціонарів, кг•га ${ }^{-1}$

\begin{tabular}{|c|c|c|c|c|c|c|c|c|c|}
\hline \multirow[b]{2}{*}{ Фракції опаду } & \multicolumn{4}{|c|}{2013 p. } & \multicolumn{4}{|c|}{$2014 \mathrm{p}}$. & \multirow[b]{2}{*}{$\begin{array}{c}\text { Всього } \\
\text { за рік }\end{array}$} \\
\hline & 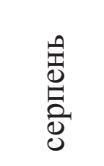 & 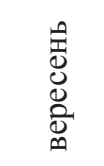 & 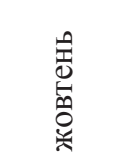 & 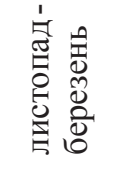 & 继 & 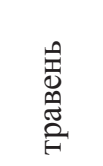 & 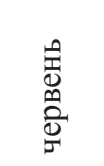 & $\begin{array}{l}\text { 恚 } \\
\text { 苟 } \\
\end{array}$ & \\
\hline 1 & 2 & 3 & 4 & 5 & 6 & 7 & 8 & 9 & 10 \\
\hline \multicolumn{10}{|c|}{ Секйія I - контроль до секиії II } \\
\hline Хвоя сосни & 83,8 & 418,2 & 331,7 & 232,0 & 18,0 & 70,9 & 42,4 & 61,3 & 1258,3 \\
\hline Листя бука & 40,3 & 140,2 & 1507,3 & 19,2 & 0,9 & 58,6 & 9,1 & 8,6 & 1784,2 \\
\hline Листя інших порід & 4,0 & 8,2 & 82,1 & 3,1 & 0,1 & 1,2 & 1,1 & 1,3 & 101,1 \\
\hline Гілки & 7,3 & 39,0 & 21,2 & 347,0 & 22,2 & 404,1 & 23,6 & 28,0 & 892,4 \\
\hline Кора & 22,3 & 48,4 & 21,9 & 171,0 & 21,7 & 51,6 & 28,4 & 31,8 & 397,1 \\
\hline Шишки сосни & 47,8 & 33,9 & 11,1 & 110,2 & 30,0 & 190,1 & 203,8 & 84,1 & 711,0 \\
\hline Горішки бука & 4,8 & 142,9 & 89,3 & 24,8 & 1,4 & 0,5 & + & - & 263,7 \\
\hline Пліски горішків бука & 10,8 & 149,2 & 88,7 & 260,5 & 28,8 & 89,4 & 6,6 & 6,6 & 640,6 \\
\hline Насіння інших порід & - & 0,5 & 5,8 & 1,7 & 0,2 & - & + & + & 8,2 \\
\hline Разом & 221,1 & 980,5 & 2159,1 & 1169,5 & 123,3 & 866,4 & 315,0 & 221,7 & 6056,6 \\
\hline \multicolumn{10}{|c|}{ Секиія II - рівномірно поступова рубка } \\
\hline Хвоя сосни & 37,7 & 164,7 & 186,8 & 120,6 & 14,1 & 48,9 & 26,6 & 28,7 & 628,1 \\
\hline Листя бука & 16,3 & 82,5 & 574,4 & 4,3 & 0,2 & 25,4 & 3,0 & 8,1 & 714,2 \\
\hline Листя інших порід & 0,4 & 1,9 & 18,4 & 4,9 & 0,2 & 0,1 & 0,2 & 0,4 & 26,5 \\
\hline Гілки & 1,5 & 34,7 & 14,1 & 162,8 & 33,2 & 106,9 & 7,3 & 9,9 & 370,4 \\
\hline Kopa & 12,6 & 25,0 & 8,9 & 79,9 & 11,5 & 27,2 & 19,2 & 14,2 & 198,5 \\
\hline
\end{tabular}


Продовж. табл. 2

\begin{tabular}{|c|c|c|c|c|c|c|c|c|c|}
\hline 1 & 2 & 3 & 4 & 5 & 6 & 7 & 8 & 9 & 10 \\
\hline Шишки сосни звичайної & 5,6 & 13,0 & 5,9 & 32,5 & 12,9 & 70,7 & 119,3 & 19,6 & 279,5 \\
\hline Горішки бука & 2,3 & 100,5 & 44,0 & 10,1 & - & 0,1 & - & - & 157,0 \\
\hline Пліски горішків бука & 2,7 & 103,1 & 42,4 & 103,6 & 6,0 & 42,6 & 2,0 & 1,7 & 304,1 \\
\hline Насіння інших порід & + & 0,2 & 1,6 & 0,9 & - & - & - & - & 2,7 \\
\hline Разом & 79,1 & 525,6 & 896,5 & 519,6 & 78,1 & 321,9 & 177,6 & 82,6 & 2681,0 \\
\hline \multicolumn{10}{|c|}{ Секиія III - контроль до секиії IV } \\
\hline Хвоя сосни & 57,6 & 358,2 & 495,6 & 206,0 & 17,6 & 35,4 & 23,5 & 40,4 & 1234,3 \\
\hline Листя бука & 26,5 & 120,8 & 1548,0 & 32,0 & 0,8 & 25,0 & 6,7 & 11,5 & 1771,3 \\
\hline Листя інших порід & 1,2 & 0,5 & 14,5 & 1,2 & - & 0,3 & 0,1 & 0,1 & 17,9 \\
\hline Гілки & 11,1 & 44,2 & 15,4 & 379,2 & 40,0 & 78,0 & 14,3 & 13,9 & 596,1 \\
\hline Кора & 18,8 & 68,1 & 22,2 & 184,7 & 20,3 & 59,8 & 24,1 & 37,1 & 435,1 \\
\hline Шишки сосни & 5,9 & 9,7 & 4,1 & 46,0 & 15,6 & 192,4 & 196,5 & 35,7 & 505,9 \\
\hline Горішки бука & 1,5 & 47,4 & 25,8 & 6,1 & - & + & - & - & 80,8 \\
\hline Пліски горішків бука & 5,4 & 31,2 & 24,5 & 92,5 & 4,4 & 15,1 & 1,0 & 0,3 & 174,4 \\
\hline Насіння інших порід & - & 0,2 & 0,4 & 0,1 & - & - & - & - & 0,7 \\
\hline Разом & 128,0 & 680,3 & 2150,3 & 947,8 & 98,7 & 406,0 & 266,2 & 139,0 & 4816,5 \\
\hline \multicolumn{10}{|c|}{ Секиія IV-групово-вибіркова рубка } \\
\hline Хвоя сосни & 36,4 & 185,0 & 160,0 & 121,8 & 9,6 & 34,4 & 18,2 & 25,5 & 590,9 \\
\hline Листя бука & 24,3 & 104,6 & 857,0 & 9,1 & 1,5 & 48,1 & 10,1 & 11,7 & 1066,4 \\
\hline Листя інших порід & 0,3 & 1,7 & 22,9 & 1,4 & - & 0,3 & + & 0,5 & 27,1 \\
\hline Гілки & 7,2 & 25,3 & 26,3 & 239,9 & 20,5 & 81,9 & 16,0 & 12,6 & 429,7 \\
\hline Kopa & 7,1 & 33,9 & 14,9 & 104,6 & 18,1 & 31,3 & 11,5 & 13,9 & 235,3 \\
\hline Шишки сосни & 7,9 & 1,3 & 11,1 & 53,0 & 7,5 & 120,8 & 78,8 & 27,8 & 308,2 \\
\hline Горішки бука & 0,8 & 49,1 & 47,7 & 7,4 & 0,7 & 0,2 & - & - & 105,9 \\
\hline Пліски горішків бука & 5,3 & 49,9 & 39,6 & 86,1 & 5,1 & 34,9 & 1,4 & 3,0 & 225,3 \\
\hline Насіння інших порід & + & 0,4 & 0,5 & 0,4 & - & - & - & - & 1,3 \\
\hline Разом & 89,3 & 451,2 & 1180,0 & 623,7 & 63,0 & 351,9 & 136,0 & 95,0 & 2990,1 \\
\hline
\end{tabular}

У зв'язку з цим варто відзначити, що значна кількість опаду в сосново-букових лісостанах зумовлюється формуванням великої кількості листя в кронах дерев бука. У загальній масі річного опаду листя бука на контрольних секціях становить найбільшу частку, зазвичай - 29,5-36,8\%, істотно меншу - хвоя сосни $(20,8-25,6 \%)$ та гілки $(12,4-14,7 \%)$. Достатньо значимою у складі опаду $є$ маса шишок сосни $(10,5-11,7 \%)$, кори дерев $(6,6-9,0 \%)$ і плісок горішків бука $(3,6-10,6 \%)$. Невеликою часткою в річній масі опаду представлені горішки бука, зазвичай - 1,7-4,3\%, листя супутніх порід - 0,4-1,7\% і найменшою - насіння супутніх порід (0,01-0,13\%).
Формування опаду відбувається впродовж усього року. Однак найбільша маса опаду формується в жовтні (35,6-44,6\%) за рахунок опадання листя деревних порід, в основному, бука лісового. Значна кількість фітомаси в сосново-букових деревостанах опадає також у вересні (14,1-16,2\%) та в осінньо-зимововесняний період (листопад-березень - 19,3-19,7\%). Невелика маса опаду в сосново-букових деревостанах Львівського Розточчя облікована і в травні (опадає 8,4-14,3\%). У вересні основну частку опаду формують хвоя сосни та листя бука, а в урожайні роки також горішки і пліски горішків бука; в осінньозимово-весняний період - гілки, хвоя сосни, кора i пліски горішків бука, у травні - гілки і шишки сосни. 
Найменша кількість мертвої фітомаси в сосново-букових деревостанах опадає в квітні (близько 2,0\%). Основними компонентами опаду в цей період є гілки, кора, шишки і хвоя сосни. Невелику частку нагромадження опаду зафіксовано також у липні (2,9-3,7 \%) і серпні (2,7-3,7\%), яка формується, в основному, за рахунок опадання хвої і шишок сосни та кори.

Загалом в сосново-букових деревостанах Львівського Розточчя восени опадає близько $60 \%$ органічної маси; взимку, а також навесні - до $15 \%$ i влітку - 11-13\%. Варто також зазначити, що наведена вище річна динаміка нагромадження опаду в сосново-букових лісостанах характерна i для сосново-дубових лісостанів Львівського Розточчя (Криницька, 2015), що забезпечується ідентичністю сезонних погодних умов та подібним типом перебігу фізіолого-біохімічних процесів у дерев бука і дуба.

Річна динаміка нагромадження окремих фракцій опаду в сосново-букових лісостанах $є$ неоднозначною. Вона залежить від особливостей функціонування та ролі відповідних органів у життєдіяльності дерев (див. табл. 2). Так, найбільша частка хвої сосни опадає, зазвичай, у вересні $(29,0-33,2 \%$ від загальної маси іiі річного опаду) або у жовтні (26,4-40,2\%); листя бука та супутніх порід - у жовтні (відповідно, 84,5-87,4 і 81,0-81,2\%), гілок - у зимовий період $(38,9-63,6 \%)$ або у травні $(13,1-$ $45,3 \%)$, кори - у зимовий період (39,7-43,1\%), шишок сосни - у травні і червні (відповідно, 26,7$38,0$ і $28,7-38,8 \%)$, горішків бука - у вересні $(54,2-$ $58,7 \%$ ), плісок горішків бука - у вересні і зимовий період (відповідно, 17,9-23,2 і 40,7-53,0\%), насіння супутніх порід - у жовтні $(57,1-70,7 \%)$.

Різке (до мінімального) зменшення опадання різних фракцій фітомаси дерев також відбувається в різні періоди річного циклу. Зокрема, хвоя сосни, листя бука і супутніх порід у найменшій кількості опадають у квітні, гілки - у серпні, кора дерев у квітні, серпні і жовтні, шишки сосни - у жовтні, горішки бука - 3 квітня по липень, пліски насіння бука - у червні і липні, насіння супутніх порід - 3 квітня по серпень.

Найбільш подібними між собою і близькими до закономірностей річного нагромадження загальної маси опаду є річні динаміки опадання хвої сосни, листя бука і листя супутніх порід. Подібними також $є$ річні динаміки опадання гілок і кори, горішків бука і насіння супутніх порід. Відмінними, як між собою, так і з іншими фракціями, $є$ річні динаміки опадання шишок сосни і плісок горішків бука.

Вплив поступових рубок головного користування на нагромадження опаду тісно пов'язаний з їх організаційно-технічними показниками. Особливо вагоме значення має інтенсивність проведення перших прийомів рубок.

За наведеними в табл. 2 результатами, в перший рік після проведення першого прийому рівномірної поступової рубки інтенсивністю $29 \%$ річна маса опаду становила лише 2681 кг/га або 44,3\%, а після проведення групово-вибіркової рубки інтенсивніс- тю 51\%, відповідно 2990,1 кг ·га ${ }^{-1}$ або $62,1 \%$ порівняно 3 контрольними секціями. При цьому закономірності річної динаміки опаду і його фракцій на обох експериментальних секціях практично не змінились i були подібними до контрольних показників.

Водночас потрібно зазначити, що висока інтенсивність рубок покращила світлове живлення листяних порід, які формують зазвичай другий ярус деревостанів, і стимулювала їхнє плодоношення. Зокрема, на секції рівномірної поступової рубки частка горішків бука у загальній масі опаду, порівняно 3 контролем, зросла в 1,3 рази, а плісок горішків бука - в 1,1 рази. На секції групово-вибіркової рубки маса горішків бука у загальній масі опаду збільшилась в 2,1, маса плісок горішків бука - в 2,2, насіння супутніх порід - в 2,9 рази порівняно з контрольними показниками.

Висновки. Нагромадження опаду та його фракцій (окрім горішків бука і насіння супутніх порід) в сосново-букових лісостанах Львівського Розточчя відбувається упродовж усього року. Річна маса опаду становить, зазвичай, 5-6 т.rа⿰ ${ }^{-1}$ в абсолютно сухому стані. Найбільша кількість опалої фітомаси формується в жовтні за рахунок опадання листя деревних порід, в основному, бука лісового, найменша - у квітні. В осінній період опадає близько $60 \%$ органічної маси; взимку, а також навесні - до $15 \%$; влітку - до 13\%. Річна динаміка нагромадження окремих фракцій опаду $є$ неоднозначною. Найбільш подібними між собою і близькими до річного формування опалої фітомаси є річна динаміка опадання хвої сосни, листя бука і листя супутніх порід.

Проведення перших прийомів поступових рубок головного користування різко зменшує кількість опаду - рівномірної поступової до 44\%, групововибіркової - до $62 \%$. Водночас річна динаміка опаду і його фракцій залишається подібною до річних закономірностей опадання фітомаси і їі складових на контролі.

\section{Список літератури}

Бондар, І.П. (2000). Кількісні та якісні показники опаду в різних типах умов місцезростання лісостанів Київського Полісся та їх вПлив на грунт. Науковий вісник Національного аграрного університету: Лісівництво, 27, 94-103. [Bondar, I.P. (2000). Quantitative and qualitative indicators of litter-fall in different types of habitat conditions of forest stands in Kyiv Polissya and their impact on the soil. Scientific Bulletin of National Agrarian University: Forestry, 27, 94-103 (in Ukrainian)]

Бутейко, А.И. (1975). Сосново-буковые леса запада Украинской ССР: автореф. дис. ... канд. с.-х. наук: 06.03.03/ Львовский лесотехн. ин-т. Львов [Buteiko, A. I. (1975). Pine-beech forests of the West of the Ukrainian SSR: PhD dissertation abstract. Lviv Forestry Institute, Lviv, Ukraine (in Russian)]

Высоцкий, Г.Н. (1950). Учение о влиянии леса на изменение среды его произрастания и на 
окружающее пространство. Курс лесоведения. Ч. II. Москва-Ленинград: Гослесбумиздат [Vysotskyi, H.N. (1950). The doctrine of the influence of forests on changes in their growth environment and the surroundings. Forestry course. P. II. Moscow-Leningrad: Hoslesbumyzdat (in Russian)]

Горшенин, Н.М., Швиденко, А.И. (1977). Лесоводство. Львов: Вища школа [Horshenyn, N. М., \& Shvydenko, A.I. (1997). Silviculture. Lviv: High School (in Ukrainian)]

Зонн, С.В. (1954). Влияние леса на почву. Москва: AH CCCP [Zonn, S. V. (1954). Impact of forest on soil. Moscow: Academy of Sciences of the Union of Soviet Socialist Republics (in Russian)]

Ковалевський, А.К. (1952). Річний опад листя в дібровах. Праиі Інституту лісівниитва $A H$ УРCP, 3, 21-24 [Kovalevskyi, A. K. (1952). Annual leaf fall in oak groves. Scientific works of Forestry Institute Academy of Sciences of the Ukrainian SSR, 3, 21-24 (in Ukrainian)]

Кременецька, Є. О. (2000). Лісівницькі особливості корінних лісостанів зеленої зони м. Києва та наукові основи покращення їхнього стану: автореф. дис. ... канд. с.-г. наук: 06.03.03 / Національний аграр. ун-т, Київ [Kremenetska, Ye. O. (2000). Silvicultural peculiarities of indigenous forests of Kyiv green zone: $\mathrm{PhD}$ dissertation abstract. National Agrarian University, Kyiv, Ukraine (in Ukrainian)]. Retrieved from http://www.irbis-nbuv.gov.ua/cgi-bin/ irbis nbuv/cgiirbis 64.exe

Криницька, О.Г. (2015). Формування опаду i підстилки в грабово-сосново-дубових деревостанах Львівського Розточчя. Наукові основи підвищення продуктивності та біологічної стійкості лісових та урбанізованих екосистем: матеріали 65-ї науково-технічної конференції професорсько-викладацького складу, наукових працівників, докторантів та аспірантів за підсумками наукової діяльності у 2014 р., 74-76. Львів, Україна: Національний лісотехнічний ун-т України [Krynytska, О.Н. (2015). Formation of litter-fall in hornbeam-oak-pine stands in the Lviv Roztoche region. In Scientific principles of improvement of the productivity and biological stability of forests and urban ecosystems, 74-76. Lviv, Ukraine: Ukrainian National Forestry University (in Ukrainian)]

Криницька, О.Г. (2015). Особливості нагромадження опаду в грабово-сосново-дубових деревостанах, сформованих на зрубах поступових рубок в умовах Львівського Розточчя. Наукові праиі Лісівничої академії наук України, 13, 76-82 [Krynytska, O. H. (2015). Peculiarities of accumulation of litter-fall in hornbeampine-oak stands formed after gradual felling in the conditions of Lviv Roztocze. Proceedings of the Forestry Academy of Sciences of Ukraine, 13, 76-82 (in Ukrainian)]. Retrieved from http://fasu.nltu.edu. ua/index.php/nplanu/article/view/100

Криницький, Г. Т. (2015). До питання про принципи та механізми функціонування лісових екосистем.
Виклики ХХІ століття та їхнє вирішення у лісовому комплексі й довкіллі: тези доповідей Міжнародної науково-практичної конференції, 63-64. Київ, Україна: Національний ун-т біоресурсів і природокористування України [Krynytskyy, H.T. (2015). On the question of principles and mechanisms of functioning of forest ecosystems. In Abstracts of the International Scientific and Practical Conference Challenges of the XXI century and their solution in the forest complex and environment, 63-64. Kyiv, Ukraine: National University of Life and Environmental sciences of Ukraine (in Ukrainian)].

Мелехов, И.С. (1980). Лесоведение. Москва: Лесная промышленность [Melekhov, I. S. (1980). Forest$r y$. Moscow: Forest Industry (in Russian)]

Морозов, Г.Ф. (1949). Учение о лесе. Москва: Гослесбумиздат [Morozov, G. F. (1949). The concept of the forest. Moscow: Hoslesbumyzdat (in Russian)]

ОСТ 56-69-83 (1984). Пробные площади лесоустроительные. Метод закладки. Москва: ЦБНТИлесхо3 [IS 56-69-83 (1984). Sample plots forest inventory. Methods of establishing. Moscow: Central Bureau of Scientific and Technical Information Forestry (in Russian)]

Остапчук, О.С. (2012). Лісовий опад та підстилка в культурах дуба звичайного в умовах Правобережного Лісостепу. Науковий вісник Національного університету біоресурсів $i$ природокористування України, 171, 186-192 [Ostapchuk, O.S. (2012). Forest litter-fall in common oak stands in the conditions of the Right-Bank Forest-Steppe zone of Ukraine. Scientific bulletin of National University of Life and Environmental Sciences of Ukraine, 171, 186192 (in Ukrainian)]

Погребняк, П.С. (1968). Общее лесоводство. Москва: Колос [Pohrebniak, P. S. (1968). General Forestry. Moscow: Kolos (in Russian)]

Похитон, П.П. (1957). Влияние древесных и кустарниковых пород на физико-химические свойства черноземной почвы. Почвоведение, 3, 40-47 [Pokhyton, P. P. (1957). Influence of tree and shrub species on the physicochemical properties of chernozem soil. Soil science, 3, 40-47 (in Russian)]

Похитон, П.П. (1958). Влияние различных древесных пород на почву. Почвоведение, 6, 49-55 [Pokhyton, P.P. (1975). The influence of various tree species on the soil. Soil science, 6, 49-55 (in Russian)]

Рибак, В.О. (2004). Вплив мішаних лісостанів на процеси грунтоутворення у свіжих соснових суборах. Науковий вісник Національного університету біоресурсів і природокористування України, 71, 27-33 [Rybak, V.O. (2004). Influence of mixed forest stands on soil formation processes in fresh pine stands. Scientific bulletin of National University of Life and Environmental Sciences of Ukraine, 71, 27-33 (in Ukrainian)]

Шумаков, В.С. (1963). Типь лесных культур и плодородие почвы. Москва: Гослесбумиздат [Shumakov, V.S. (1963). Types of forest crops and soil fertility. Moscow: Hoslesbumyzdat (in Russian)] 
Яхницький В.Й. (2015). Таксаційна характеристика науково-виробничого стаціонару «Великопільський», закладеному в сосново-букових деревостанах Страдчівського навчальновиробничого лісокомбінату НЛТУ України. Наукові основи підвищення продуктивності та біологічної стійкості лісових та урбанізованих екосистем: матеріали 65-ї наук.-технічної конференції професорсько-викладацького складу, наукових працівників, докторантів та аспірантів за підсумками наукової діяльності у 2014 р., 138142. Львів: Україна: Національний лісотехнічний ун-т України [Yakhnytskyi, V.Y. (2015). Taxation characteristics of the scientific stationary "Velikopilskiy», established in the pine-beech tree stands of the Stradchiv wood-packing facility of the Ukrainian National Forestry University. In Scientific principles of improvement of the productivity and biological stability of forests and urban ecosystems, 138-142. Lviv: Ukraine: Ukrainian National Forestry University (in Ukrainian)]

Krynytska, O., Bondarenko, T., Capuliak, J., \& Trenčiansky, M. (2017). Quantitative analysis of litter-fall in hornbeam-oak-pine stands in the Lviv Roztoche region. Central European Forestry Journal, 63 (1), 35-41. https://doi.org/10.1515/forj-2017-0004

\section{Dynamics of litterfall in pine-beech stands and its changes under the influence of uniform shelterwood felling in the Lviv Roztocze region}

\section{Yakhnytskyi', H. Krynytskyy ${ }^{2}$}

Quantitative and qualitative indicators of precipitation depend on many factors such as the composition of plant species, forestry activities, seasonal features of the year, climate and soil hydrological features in the region, etc. Of particular importance for the formation of litter-fall is the stand and its silvicultural and taxonomic features, which are the main component of the forest.

In this work, the peculiarities of the annual dynamics of litterfall accumulation and its structural fractions are characterized (pine needles, beech leaves, leaves of accompanying breeds, branches, bark, pine cones, beechnuts, beechnut cupules, seeds of accompanying breeds) and their changes after the first methods of shelter wood felling of the main-use is unique in

Volodymyr Yakhnytskyi - aspirant of the Forestry Department of Ukrainian National Forestry University, Gen. Chuprynka str., 103, Lviv, 79057, Ukraine. Tel.: +38-096-021-11-92. E-mail: krynytsk@, ukr.net

Hryhoriy Krynytskyy - scientific Director, full Member of the Forestry Academy of Sciences of Ukraine, President FAS of Ukraine, doctor of Biological Sciences, Professor, Head of the Department of Forestry. Ukrainian National Forestry University. 103 General Chuprynka str., Lviv, 79057, Ukraine. Tel.: 032-23789-05, +38-067-784-11-60. E-mail: krynytsk@ukr.net composition and limited in distribution pine-beech forests in Lviv Roztocze region. It was found that, depending on the biometric indicators of mature pinebeech stands, the annual rainfall is usually $5-6 \mathrm{t} /$ ha in a dehydrated state. The largest share of litterfall in the annual cycle is beech leaves (29.5-36.8\%) and much smaller pine needles (20.8-25.6\%). Quite significant in the composition of the precipitation is the mass of branches (12.4-14.7\%), pine cones $(10.5-11.7 \%)$, tree bark (6.6-9.0\%), and beechnut cupules (3,6-10.6\%). A small share of litterfall is represented by beech nuts (1.7-4.3\%) and leaves of accompanying breeds (0.4$1.7 \%$ ) and the smallest by seeds of accompanying breeds $(0.01-0.13 \%)$.

The largest mass of litterfall is formed in October (35.6-44.6\%) due to defoliation, mainly beech. A significant amount of dead phytomass also falls in September (14.1-16.2\%) and in the autumn-winterspring period (November - March, 19.3-19.7\%). A small increase in litterfall accumulation in the pinebeech stands of Lviv Roztocze is also typical in May (8.4-14.3\%). In September, the main share of litterfall is formed by pine needles and beech leaves, and in fruitful years it is also represented by beech nuts and beechnut cupules; in the autumn-winter-spring period branches, pine needles, the bark of beech and beechnut cupules; in May - pine branches and cones. The lowest amount of phytomass falls in April (about $2.0 \%$ ). During this period, the main components of litterfall are represented by pine branches, bark, cones, and pine needles. A small share of litterfall is also observed in July (2.9-3,7\%) and August (2.7-3.7\%), formed mainly by the fall of cones, bark and pine needles. In general, in pine-beech stands of Lviv Roztocze, about $60 \%$ of organic matter falls in autumn, in winter, and spring up to $15 \%$ and in summer $-11.0-13.0 \%$.

The annual dynamics of accumulation of individual litterfall fractions in pine-beech forests are ambiguous. It depends on the functioning and role of the relevant organs in the life of trees. The largest mass of pine needles falls in September (29.0-33.2\%) or in October (26.4-40.2\%), beech leaves and accompanying breeds in October (84.5-87.4 and $81.0-81.2 \%$ respectively), branches in winter (38.9-63.6\%) or in May (13.1$45.3 \%)$, bark in winter $(39.7-43.1 \%)$, pine cones in May and June (26.7-38.0 and 28.7-38.8\% respectively), beech nuts in September (54.2-58.7\%), beechnut cupules in September and winter (17.9-23.2 and 40.7$53.0 \%$ respectively), seeds of accompanying breeds in October $(57.1-70.7 \%)$.

The smallest amount of litterfall of different fractions of trees phytomass also occurs in different periods of the annual cycle. Pine needles, beech leaves and accompanying breeds fall at a minimum amount in April, branches - in August, tree bark - in April, August and October, pine cones - in October, beech nuts - from April to July, beechnut cupules - in June and July, the seeds of accompanying breeds - from April to August. The most identical and close to the total mass of litterfall's annual accumulation patterns are the annual dynamics of pine needle litter, beech leaves, and leaves 
of accompanying breeds. The annual dynamics of litterfall of beech branches, bark and nuts, and seeds of accompanying breeds are similar. The annual dynamics of pine cones and beechnut cupules are different, both among themselves and other fractions.

The impact of shelterwood feelings of the main-use on the litterfall accumulation is closely related to their organizational and technical indicators, particularly the intensity of feeling.

After the first stage of shelterwood uniform felling, the annual mass of litterfall decreased to $44.3 \%$, and group-shelterwood felling - to $62.1 \%$ compared to the control, while the annual dynamics of litterfall and its fractions after felling did not change significantly.

Simultaneously, it should be noted that felling improves the light supply of deciduous species, which form mainly the second layer of trees and stimulate their fruiting. As a result, in the section of shelterwood uniform felling, the share of beech nuts in the total mass of litterfall, compared with the control, increased 1.3 times, and the beechnut cupules -1.1 times. In the group-shelterwood felling section, the number of beechnuts and beechnut cupules increased 2.1 times, and the number of seeds of accompanying breeds -2.9 times compared to the control values.

Key words: pine; beech; accompanying breeds; annual cycles; phytomass precipitation; litterfall fractions; shelterwood uniform felling and groupshelterwood felling.

\section{Динамика опада в сосново-буковых древостоях и ее изменения под влиянием постепенных рубок в условиях Львовского Расточья}

\section{В.И. Яхницкий ${ }^{1}$, Г.Т. Криницкий ${ }^{2}$}

Освещены особенности годовой динамики накопления опада и его структурных фракций (хвоя сосны, листья бука, листья сопутствующих по-

Яхничкий Владимир Иосифович - соискатель кафедры лесоводства. Национальный лесотехнический университет Украины, ул. Генерала Чупринки, 103, г. Львов, 79057, Украина. Тел.: +38-096-021-11-92. E-mail: krynytsk@ukr.net

Криницкий Григорий Томкович - научный руководитель, академик Лесной академии наук Украины, президент ЛАН Украины, профессор, заведующий кафедрой лесоводства. Национальный лесотехнический университет Украины, ул. Генерала Чупринки, 103, г. Львов, 79057, Украина. Тел.: 032-25842-05,+38-067-784-11-60. E-mail: krynytsk@ukr.net род, ветки, кора, шишки сосны, орешки бука, плюски орешков бука, семена сопутствующих пород) и их изменений после проведения первых приемов равномерных постепенных и группововыборочных рубок главного пользования в уникальных за составом и ограниченных по распространению сосново-буковых насаждениях Львовского Расточья. Установлено, что в зависимости от лесоводственно-таксационных показателей спелых сосново-буковых древостоев годовая масса опада составляет, как правило, 5-6 т.га⿰ $\mathrm{a}^{-1}$ в абсолютно сухом состоянии. Наибольшую часть опада в годовом цикле составляют листья бука $(29,5-36,8 \%)$, значительно меньшую - хвоя сосны $(20,8-25,6 \%)$. В достаточно большом количестве в составе опада представлена масса веток (12,4-14,7\%), шишек сосны $(10,5-11,7 \%)$, коры $(6,6-9,0 \%)$ и плюсок орешков бука $(3,6-10,6 \%)$. Небольшую часть опада составляют орешки бука $(1,7-4,3 \%)$ и листья сопутствующих пород (0,4-1,7\%), наименьшую - семена сопутствующих пород $(0,01-0,13 \%)$.

Наибольшая масса опада формируется в октябpe $(35,6-44,6 \%)$, значительно меньше - в сентябpe $(14,1-16,2 \%)$ и на протяжении ноября-марта (19,3-19,7\%). Небольшая масса опада в сосновобуковых насаждениях наблюдается и в мае $(8,4-$ $14,3 \%)$. Наименьшее количество фитомассы опадает в апреле (около 2,0\%). Небольшая часть опада зафиксирована также в июле $(2,9-3,7 \%)$ и августе $(2,7-3,7 \%)$.

Наибольшая масса хвои сосны опадает в сентябре $(29,0-33,2 \%)$ или в октябре $(26,4-40,2 \%)$, листьев бука и сопутствующих пород - в октябре (соответственно, 84,5-87,4 и 81,0-81,2\%), веток - в зимний период $(38,2-63,6 \%)$ или в мае $(13,1-45,3 \%)$, коры - в зимний период (39,7-43,1\%), шишек сосны - в мае и июне (соответственно, $26,7-38$ и $28,7-38,8 \%$ ), орешков бука - в сентябре $(54,2-58,7 \%)$, плюсок орешков бука - в сентябре и зимний период (соответственно, 17,9-23,2 и 40,7$53,0 \%)$, семян сопутствующих пород - в октябре $(57,1-70,7 \%)$.

После проведения первых приемов равномерной постепенной рубки годовая масса опада уменьшилась до $44,3 \%$, а группово-выборочной - до $62,1 \%$ по сравнению с контролем. При этом годовая динамика опада и его фракций после рубок существенно не изменилась.

Ключевые слова: сосна; бук; сопутствующие древесные породы; годовые циклы; опадание фитомассы; фракции опада; равномерная постепенная и группово-выборочная рубка. 